beskrivelse av forholdene i Hellas er ganske enkelt skremmende. Enkelte steder er forholdene så ille at man isolerer de pasientene som ikke har infeksjoner med multiresistente bakterier. Kampen anses tapt.

Problemene er mange - og svikt forekommer ofte. Ett av mange lærerike eksempler henter han fra Akademiska Sjukhuset i Uppsala. I 2002 lanserte de prosjektet «Smittfritt», med fokus på MRSA. Med den reklamen fikk de mange pasienter både fra inn- og utland - i 2004 kom det 1,5 milliarder svenske kroner fra eksterne pasienter. Da det sommeren 2005 dukket opp multiresistente Klebsiella-stammer tok det lang tid før ledelsen erkjente dette. Forfatteren undrer seg - med rette.

Selv om forholdene i Sverige skiller seg noe fra de i Norge, er det mange fellestrekk som giør at boken vil være nyttig lesing for mange. Helsepolitikere på alle plan, registreringsmyndigheter ikke unntatt, står øverst på listen. Boken burde være obligatorisk lesing for alle konsulenter som utreder nedlegging av sengeplasser, flytting av avdelinger, redusering av viktig service som mikrobiologiske undersøkelser osv. Boken vil også kunne gi mange leger nytt mot til å si fra når dårskapen blir for uttalt. Farene med helseturisme kommer klart frem, enten det skjer på frivillig basis eller for å redusere helsekøene. Boken vil være nyttig for dem som kjemper for å bevare lokalsykehusene og også for kommunale aktører som får et større ansvar fra 2012. Forfatterens egenerfaring fra «öppen vård» og hans syn på bruk av antibiotika - redselens medisin - vil være verdifull lesing for mange allmennpraktikere.

Boken er velskrevet, lettlest og oppdatert. Det understrekes at antibiotikaresistens er overlegent den farligste og viktigste bivirkningen, og at resistensfaktorer sprer seg raskt globalt, ikke bare med pasienter, men med friske bærere, matvarer osv.

Mange har ropt ulv lenge uten å bli hørt, nå herjer en hel flokk!

\section{Tore Midtvedt}

Konsulent ved Unilabs Telelab

Oslo

\section{Mennesket i et evolusjonistisk perspektiv}

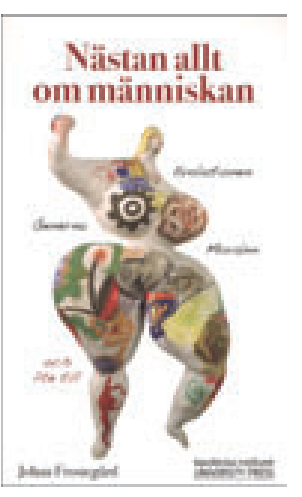

Johan Frostegård

\section{Nästan allt om människan}

Evolutionen, generna, moralen och lite till.

296, ill. Stockholm: Karolinska Institutet

University Press, 2011. Pris SEK 74

ISBN 978-91-85565-44-3

Dette er et ambisiøst prosjekt med det siktemål å omtale mennesket og dets sykdommer fra en evolusjonær synsvinkel. Forfatteren er professor og medisinsk forsker ved Karolinska Institutet i Stockholm. Det opplyses at han har gitt ut to romaner, uten at det sies noe om hvordan hans skjønnlitterære virksomhet er blitt mottatt og vurdert.

16 kapitler spenner fra bl.a. evolusjonsteoriens historie til etikk, moral og evolusjon og evolusjonsteoriens relevans for sykdomsbekjempelsen. Det er ingen liten oppgave å skulle gi en meningsfylt innføring i så mange kunnskapsområder. I antikken og i noen grad også i renessansen var det mulig for en enkeltperson å tilegne seg den totale foreliggende viten om mennesket og verden, og betegnelsen «polyhistor» ble brukt om en person som hadde innsikt og viten på mange forskjellige vitenskapelige områder.
Polyhistorens tid er forlengst forbi. Men behovet for tverrfaglighet er ikke blitt mindre enn før. I superspesialistenes tid trengs det personer som kan sette sammen kunnskap fra flere felter til et meningsfylt hele. I kunnskapsformidlingens tjeneste er det viktig at noen påtar seg en slik oppgave.

Hos Frostegård er den biologiske evolusjon den røde tråd som på et vis holder teksten sammen. Har forfatteren lyktes i sitt formidlingsprosjekt? Etter min mening er svaret både ja og nei. Som medisinsk forsker er han godt orientert om hvor forskningsfronten er innen de fleste medisinske disipliner. Han er også godt orientert om utviklingslæren, uten å ha formell evolusjonsbiologisk kompetanse. Meget prisverdig påpekes mangelen på evolusjonistisk tenking i medisinen. Folkesykdommer som overvekt og type 2-diabetes kan verken forstås eller behandles adekvat uten å legge den biologiske utvikling til grunn.

Svakest kommer forfatteren ut der han drøfter menneskets kulturelle og hva vi kan kalle åndelige sider. Når han skriver om bevisstheten (medvetande) og «sjelen», har han etter min mening ikke den nødvendige respekt for emnets vanskelighetsgrad. Det er ikke lett å forstå hva han mener med sjel (s. 101): «Själen har et biokemiskt underlag», sier han, «i likhet med tankar och känslor». Det kan vel ikke være sjel i religiøs betydning han da tenker på. Jeg antar at man i Sverige liksom i Norge kan tale om sjel også i en ikke-religiøs forstand, som en betegnelse på vårt åndelige liv og da nettopp våre «tankar och känslor». Forfatteren reiser også det originale spørsmål om «individer som haft en större grad av medvetande och «själsliga» förmågor har haft en fördel när de gäller reproduktion». I det 11 sider lange kapitlet Etikk, moral og evolusjon blir man stadig minnet om hva forfatteren selv mener, gjennom formuleringer som «själv är jag benägan att tro....» og «själv har jag svårt att se...».

Jeg har ikke systematisk jaktet på feil, men på s. 40 blir formuleringen «survival of the fittest» tillagt Thomas Henry Huxley (1825-95), det skal være Herbert Spencer (1820-1903). At forfatteren ikke nevner Rosalind Franklin (1920-58) i forbindelse med klarleggingen av DNA-strukturen, får være tilgitt. Mange andre har gjort den feilen.

Boken er skrevet i en kåserende stil med en refererende tekst. Innholdet er verken dyptpløyende eller analytisk. Man bør kanskje ikke ta tittelen, Nästan allt om människan, helt alvorlig. Likevel melder spørsmålet seg om denne har en mening utover det salgstekniske.

Det er ikke klart hvem forfatteren primært skriver for. Er det den svenske legestanden? Noen ganger fornemmer man at forfatteren henvender seg til «folk flest», andre ganger synes målgruppen å være noe i retning av en særdeles godt opplyst allmennhet.

Boken har et hendig format $(10 \times 17 \mathrm{~cm})$, men lesbarheten er dårlig, særlig for eldre mennesker, pga. altfor små bokstavtyper. Forunderlig nok er undertitlene ikke uthevet, men tvert imot satt med svakere typer enn den øvrige teksten. Boken er utstyrt med noter, litteratur og stikkordsliste.

I kjølvannet av programserien Hjernevask og spørsmålet om du er «født sånn» eller «blitt sånn», kunne en bok som dette ha en potensiell leserkrets her i landet. Men den fortjener ikke å bli oversatt til norsk.

Oddmund Søvik

Institutt for klinisk medisin

Universitetet i Bergen 